\title{
EU TRADEMARKS FOR WINE WHICH CONTAINS INDICATIONS OF GEOGRAPHICAL ORIGIN
}

\author{
Sonja Lučić ${ }^{1}$ \\ *Corresponding author E-mail: spasojevic.sonja@yahoo.com
}

\begin{abstract}
A R T I C L E I N F O
A B S T R A C T

Review Article

Trademarks and indications of geographical origin have

Received: 18 February 2018

different legal nature. Main difference is that trademarks

Accepted: 17 May 2018 indicate origin of goods from specific business entity and doi:10.5937/ekoPolj1802715L UDC 339.13+663.2]:347.77(4-672 EU) indications of geographical origin refers to geographical origin of goods. In an effort to find suitable forms of labelling their product, manufacturers are also using

Keywords:

EU trademark, Regulation 1308/2013, Absolute ground for refusal, Trademark for wine

JEL: K00, K15, K33 indications of geographical origin. In other words, beside the difference that exists between trademarks and indications of geographical origin, in practice there are cases when indications of geographical origin is used as subject of submitted or registered trademark. Registration practice of indications of geographical origin as trademarks is very restrictive today and it is allowed only under special conditions. In this work we will analyze connection between indications of geographical origin for wines related to the EU trademark in the light of the current EU regulations and most recent practice of the Court of Justice of the European Union.
\end{abstract}

(C) 2018 EA. All rights reserved.

\section{Introduction}

Indications of geographical origin protected in the European Union might represent interference for registration, grounds for complaint and suspension of the EU trademark. On the other hand, the EU trademark can be registered for numerous products and services. When marking wine, alcohol beverages, agricultural and food products, specific European regulations regarded these products must be considered. These regulations have also direct effect on trademark right (Loschelder, 2015). Probability that the EU trademark is in collision with indications of geographical origin is much higher than expected. In the EU trademark register more than 40.000 trademarks are entered into the class 33 of the Nice Agreement (alcohol beverages, except bear). Of that number, nearly 9.000 are trademarks which for subject of its protection has sign containing term wine. Electronic register of protected designations of origin and protected geographical indications for wine (E-Bacchus) contains about 3.300 registrations, which are in mutual effect with the trademarks of the Union.

1 Sonja Lučić Ph.D., Assistant Professor, University of Kragujevac, Faculty of Law, Jovana Cvijića 1, 34000Kragujevac, Serbia, phone number: +38163612786, e-mail: spasojevic. sonja@yahoo.com, http://orcid.org/0000-0002-7104-3572. 
Geographical terms cannot be registered as trademarks upon three grounds: non distinctivity of the mark, i.e. lack of differentiation power, need that mark stay free in traffic and provoking misbeliefs about geographical origin of the product. Also, the question of registration indications of geographical origin as trademarks may be considered in two different situations. The first one is considering registration of geographical terms as trademarks for products that are not originate from mentioned geographical area, while in another situation we have registration of geographical terms as trademarks for products that are originated from that geographical area. Besides that national and supranational regulations predicts absolute disturbances for registration of geographical indications as trademark, in practice there are frequent cases in which same geographical indication is used as subject of two different and competitive rights: trademark right and right to a geographical indication. Practical problems arise due to incompliance of the circle of authorized persons on the older and younger sign. The controversial question that arises in this case is actually the question of the scope of rights that rights owners can emphasize, both in mutual relations and also toward third party. Therefore the need to formulate collision solution in national and supranational regulations.

Indications of geographical origin represent a kind of national resource. As an integral part of intellectual property rights they could become the main promoters of the Serbian economy and the country's expression of identity because the notion of quality of products is directly transmitted to the country's reputation (Jovićević-Simin, Jovićević, Novaković, 2016). Owing to the natural, ecological and environmental characteristics, different rural areas are a very interesting and promising for the development of rural tourism (Vuković, Cecić, Cvijanović, 2007). Wine tourism is an important channel for attracting tourists and developing rural areas (Sekulić, Mandarić, Milovanović, 2016). Yet, wine tourism in Serbia is not quite recognized as a priority although it can generate numerous benefits for the tourism, economy and society in general (Jojić-Novaković, Cvijanović, 2017). Serbia has the potential for the development of wine tourism (Vujko, Gajić, Gudurić, 2017). Geographical indications allow consumers outside our country to recognize the wines from Serbia. Considering the intention of Serbia to join the EU and the WTO (The World Trade Organisation), the experiences of the Old and the New World are precious. An important step towards this goal is the Stabilization and Association Agreement of the EU, by which signing Serbia, among other things, undertook commitment to ensure the level of protection of intellectual property rights similar to the existing protection in the EU, including effective means for exercising these rights. In the following sentences we will analyze specific European regulations considering connections between the EU trademarks for wine and indications of geographical origin.

\section{The most important changes in Regulation 2015/2424}

One of the most notable changes in Regulation 2015/2424 and related to the subject of this work is included in the Article 7, paragraph $1(\mathrm{j})$ of Regulation. This Article is now modified as norm which implify at specific European right considering protection of the indications of geographical origin for all products. Reference to the EU law, 
but also at national law and international agreements, were not foreseen in the text it's self of the previous Regulation. Because of that, it was unclear if other EU regulations can even be applied, considering that the European Union Intellectual Property Office in principle decides based on the Regulation 2015/2424, and not other regulations. The link between Regulation 207/2009 (now Regulation 2015/2424) and Regulation $1308 / 2013$ on the establishing joint organization of the agricultural products market was subject of decision of the Court of First Instance in the case CUVÉE PALOMAR (Case T-237/08). In the following text factual situation of this case will be presented.

On 27 November 2006 the applicant filed a Community trade mark application at the Office for Harmonisation in the Internal Market, pursuant to Regulation No 40/94. The trade mark for which registration was sought is the word sign CUVÉE PALOMAR. The examiner, taking the view that the mark applied for was inadmissible on the basis of the absolute ground for refusal referred to in Article 7(1)(j) of Regulation No 40/94, refused the application for registration by decision of 5 June 2007.The applicant appealed against the examiner's decision. By decision of 2 April 2008 the First Board of Appeal dismissed the appeal and ordered the applicant to pay the costs incurred relating to the procedure. The Board of Appeal points out that it is apparent from a comparison of Article 22(3) and Article 23(2) of the TRIPS Agreement (The Agreement on Trade-Related Aspects of Intellectual Property Rights) that the latter provision, the wording of which was incorporated into Article 7(1)(j) of Regulation No 40/94, constitutes a lex specialis, which lays down a specific prohibition on registration of geographical indications identifying wines and spirits. That prohibition is, according to the Board of Appeal, absolute and unconditional, since it is not subject to the condition that the use of the geographical indication in the mark for those goods be such as to deceive the public on the actual place of origin, a condition to which application of the general prohibition on registration of geographical indications referred to in Article 22(3) of the TRIPS Agreement is explicitly subject. The Board of Appeal states, in essence, that el Palomar is the name of a local administrative area in the sub-region Clariano and constitutes, pursuant to the applicable Community and national law, an area of production protected by the registered designation of origin "Valencia". Given that the protection of registered designations of origin extends to the names of local administrative areas, in the present case el Palomar, and to words which may on account of their similarity create confusion, as is the case with the word "Palomar" included in the mark applied for, the Board of Appeal states that the presence of that word in the Community mark applied for is understood, pursuant to the applicable legislation, as a geographical indication identifying a wine. The Court finally decided: dismisses the action.

Link between Regulation 207/2009, relating trademark for wine containing geographical indication and Article92 (ff) of Regulation 1308/2013 is TRIPS. On this basis the European Union has published rules in two directions. For trademarks which refers to wine, harmonization was done in Art. 7, paragraph 1(j) of Regulation 207/2009, which relies on Art. 23, paragraph 2 of the TRIPS. According to this regulation, registration of wine trademark which consist of geographical indication, will be denied or cancelled 
if that trademark doesn't indicate to a true origin of the wine. Conditions and the scope of protection of the indications of geographical origin are stipulated in Section 2, Art. 92 (and further) of Regulation 1308/2013. These regulations are aligned with Art. 23 and 24 of the TRIPS. These complicated connection, which the Court of First Instance had to done among Regulation 207/2009 and Regulation 1308/2013, by entry into force of Regulation 2015/2424 is set up on dogmatic grounds. Before changes were done, Article 7, paragraph 1 (j) of Regulation 207/2009 contained rule which was only partly coincidence with Article 102, paragraph 1 of Regulation 1308/2013.This led to numerous dilemmas during its application. Modification in Regulation 2015/2424 lead to simplifying law enforcement, considering that now only appropriate rules of Regulation 1308/2013 are enforced. These rules will be analyzed in the following sentences. Other changes are included in the Article 7, paragraph $1(\mathrm{k})$ of Regulation $2015 / 2424$, and gives the answer to the question what is the role of traditional terms for wine. This Regulation in Article 8, paragraph 4 (a) strictly predicts possibility of submitting objection against Union trademark which consist of geographical indication. Besides that, in Article 53, paragraph 1 (d) reasons for relative nullity are prescribed.

\section{Indications of geographical origin as absolute disturbances for registration Union trademark}

According to Ar. 7, paragraph 1 (j) of Regulation 2015/2424, trademarks which are excluded from registration, pursuant to Union legislation or national law or to international agreements to which the Union or the Member State concerned is party, providing for protection of designations of origin and geographical indications. Referring to national law, the Court of Justice of the European Union has already confirmed in its practice (Ströbele, Hacker, 2015). It is significant that referring to EU law, first of all to Art. 92(ff) of Regulation 1308/2013. Besides that, referring to international agreements is important. Process of registration indications of geographical origin is regulated in the Articles 93-101 of Regulation 1308/2013. This is the central form on which Regulation 2015/2424 at Article 7, paragraph 1 (j) are pointing out.

\section{Definition of designations of origin and geographical indications according to Regulation 1308/2013}

Regulation 1308/2013 contains in Article 93 definition of indications, which are also included in Article 7, paragraph 1 (j) of Regulation 2015/2424.Definition of indications of geographical origin in Regulation 1308/2013 is referred only to wine, and not to other products, such as alcohol beverages, agricultural and food products. Based on it, this Regulation, among other things, is different from other similar regulations. Before Regulation 2015/2424 come into force, it was unclear does the definition of indications of geographical origin from Article 93 of Regulation 1308/2013, has a definite character for the application of Article 7, paragraph 1 (j) of Regulation 207/2009. This dilemma was solved after Regulation 2015/2424 came into force. This question was also a matter of decision of the Court of First Instance in the case "LEMBERGERLAND" (Case 
$\mathrm{T}-55 / 14)$. In the following text factual situation of this case will be shortly presented. On 22 August 2012, the applicant filed an application for registration of a Community trade mark at the Office for Harmonisation in the Internal Market. The mark in respect of which registration was sought is the word sign "LEMBERGERLAND". By decision of 30 January 2013, the examiner rejected the application for registration of the goods indicated in paragraph 3 above, on the ground that the mark applied for was covered by the absolute ground for refusal referred to in Article 7(1)(j) of Regulation No 207/2009. On 25 March 2013 the applicant lodged an appeal with Office for Harmonisation in the Internal Market (OHIM), pursuant to Articles 58 to 64 of Regulation No 207/2009, against the examiner's decision. By decision of 14 November 2013, the First Board of Appeal of OHIM dismissed the action. It found that the mark applied for contained the geographical indication Lemberg, protected in the European Union for wines originating from South Africa under Article 8(b)(ii) of the Agreement between the European Community and the Republic of South Africa on trade in wine, read in conjunction with Annex II to that Agreement, whilst the wine subject of the mark applied for did not originate from that place of provenance. It took the view that the mark applied for was not simply a new fanciful word in relation to the geographical indication Lemberg and that, in order to justify the refusal of its registration on the ground referred to in Article 7(1) (j) of Regulation No 207/2009, it sufficed that it contained or consisted of elements which enabled that geographical indication to be identified with certainty.

The Court in the verdict (Case T-55/14) confirmed that terms from annex of a bilateral agreement are to be understand as geographical indications in the sense of Art. 7, paragraph 1 (j) of Regulation 207/2009. From this we may conclude that definition of indications of geographical origin from Regulation 1308/2013 is not final. The Court has even stated that definition from the Regulation is irrelevant for indications of geographical origin originated in a third country. Only adequate bilateral agreement is relevant. This verdict has confirmed link between bilateral agreement and Regulation 1308/2013. Definition in Art 93 of Regulation points to geographical indications from a third countries, which also can be protected according to provision of this Regulation. The Agreement between the EU and South Africa, on the other hand, refers to definition of geographical indications from TRIPS, which is without further ground of the 1Regulation 1308/2013, Regulation 207/2009 and Regulation 2105/2424.

\section{Link between trademarks and indications of geographical origin}

Link between trademarks and indications of geographical origin is regulated in Regulation 1308/2013, Art. 102, paragraph 1 which reads: "The registration of a trade mark that contains or consists of a protected designation of origin or a geographical indication which does not comply with the product specification concerned or the use of which falls under Article 103(2), and that relates to a product falling under one of the categories listed in Part II of Annex VII shall be: (a) refused if the application for registration of the trade mark is submitted after the date of submission of the application for protection of the designation of origin or geographical indication to the Commission and the designation of origin or geographical indication is subsequently protected; or (b) invalidated". 
The trademark application is rejected, or the registered trademark is declared invalid if the trademark consists of or contains a protected geographical indication. The European Union Intellectual Property Office (EUIPO) has abolished refusal of registration trademark MICHEL LEON for wine, because indications of geographical origin "Tierra de León" and "Castilla y León" are not included in trademark (Klein, 2016). In their decision the Council has stated that application of Art. 7, paragraph 1(j) of Regulation 207/2009 is considered only if submitted trademark contains indication of geographical origin completely. Both indications of geographical origin contains geographical term "León", which has power of marking. This is a town in the northwest Spain. Other constituent, "Tierra de" and "Castilla" have descriptive character, i.e. have small straight of marking. These descriptive marks are entered in the database E-Bacchus with León as constituent part, as a result, elements of descriptive character have distinctive power in the entire mark. Because of that, participants in the trade can not associate reported trademark with protected geographical indication. On contrary, in the opinion of the Council, participants in the trade associate reported trademark with personal name. For this reason, trademark does not affect the main function of the indication of geographical origin, and that is indication of the region from which the wine originates.

Similar EUIPO has made, in decision "HACIENDA ZORITA DUERO VALLEY" (Klein, 2016). Reported trademark consisted only part of the protected indications of geographical origin "Ribera del Duero" (meaning riverbank of the Duero in Spanish). Most of the elements consisting the trademark have descriptive character, because of that Art. 7, paragraph 1(j) of Regulation 207/2009 could not be applied. For appliance of this regulative, in this very case, trademark must contains protected indications of geographical origin entirely. Following cumulative condition for not allowing trademark registration, apropos extinguishing already registered trademark in the context of Art 102, paragraph 1 of Regulation 1308/2013, is that reported trademark is incompatible with product specification to which protected indication of geographical origin is related. This means that every participants in the trade can use protected indication of geographical origin for wine originated from region on which specific indication pointing. Registration of trademark in this case, must be restricted only to wines in relation to other products from class 33 . Under this condition registration of trademark matches product specification to which protected indication of geographical origin is related to. Regulation 1308/2013 in Art. 102, paragraph 1, prescribe alternative conditions under which registration of trademark is denied, i.e. registered trademark extinguishes. The condition is that application of trademark is in line with some factual state mentioned in Annex VII part II of Regulation. In the text that follows factual states from Art. 103, paragraph 2 of Regulation 1308/2013 will be analyzed.

\section{Protection against every direct or indirect commercial use of protected name}

On this form of violation of protected indication of geographical origin the Court of Justice of the European Union had opportunity to declare in the case "BNIC COGNAC" (Case C-4/10). The name "Cognac" enjoys protection based on Regulation 110/2008 for 
brandy made of white grape, originated from French region of the same name. ${ }^{2}$ Dispute about name "Cognac" emerged between French association "Bureau national interprofessionel du Cognac" (BNIC), which presents cognac manufacturers and Gust. Finnish law association, which on 19 December 2000 submitted to Finnish National Board of Patents and Registration request for registration of two figurative trademarks. The first trademark is related to a brandy and besides the figurative element it contained also the endorsement "COGNAC L\&P HIENOA KONJAKKIA Lignell\&Piispanen Product of France $40 \%$ vol. $500 \mathrm{ml}$ ". The second trademark was submitted for wine based liqueur, and besides figurative element contained also the endorsement " $K A H V I$ KONJAKKI Cafe Cognac Likööri - Likör - Likueur 21 \% VolLignell\&Piispanen 500 $m l$ ". The National Board of Patents and Registration approved registration of both trademark on 31 January 2003. In the meantime, regarding objection which BNIC submitted, the Board confirmed validity of the first trademark, and decided to extinguish the second one. Soon after, Board of Appeal rejects the appeal submitted by BNIC, and adopt appeal submitted by owner of disputed trademarks, which abolished previous decision on extinguishing the second trademark. That was the motive for BNIC to initiate proceedings in front of the Supreme Administrative Court and requests for abolition of Board of Appeal s decision, or, failing which, the referral of the case back to the National Board of Patents and Registration. Meantime, the Court has adjourned the case, which was initiated before it and initiated preliminary decision procedure before the Court of Justice of the European Union by bringing four questions.

In its verdict, the Court taken a stand that controversial trademark, which, among other, contains the term "Cognac", represent direct use of protected indication of geographical origin. But the Court did not gave the further explanation of the terms direct and indirect. On direct and indirect application of the protected indication of geographical origin, the Court of First Instance, also had a chance to decide in the case PORT CHARLOTTE (Case T-659/14). Registration as a mark was sought for the word sign PORT CHARLOTTE. The applicant, Instituto dos Vinhos do Douro e do Porto filed an application with OHIM for a declaration that the contested mark was invalid pursuant to Article 53(1)(c), read in conjunction with Article 8(4), Article 53(2)(d), and Article 52(1)(a), read in conjunction with Article 7(1)(c) and (g) of Regulation No 207/2009. In support of its application for a declaration of invalidity, the applicant relied on the appellations of origin "porto" and "port", which it claimed (a) were protected, in all the Member States, by several provisions of Portuguese law and by Article 118m(2) of Council Regulation (EC) No 491/2009 amending Regulation (EC) No 1234/2007 establishing a common organisation of agricultural markets and on specific provisions for certain agricultural products and (b) were registered and protected under the Lisbon Agreement for the Protection of Appellations of Origin and their International Registration. By decision of 30 April 2013, the Cancellation Division rejected the application for a declaration of invalidity. On 22 May 2013, the

2 The term „Cognac“, regardless protection which exists under the French law, in the EU law enjoys protection since 15 June 1989. See Annex II, Regulation 1576/89. 
applicant filed a notice of appeal with OHIM, pursuant to Articles 58 to 64 of Regulation No 207/2009, against the decision of the Cancellation Division. By decision of 8 July 2014 the Fourth Board of Appeal of OHIM dismissed the appeal. In it's verdict the Court has stand that in the trademark "PORT CHARLOTTE" there isn't either direct or indirect use of protected names "Port", "Porto" or "Oporto". Under the opinion of the Court, trade will understand mark PORT CHARLOTT as designation for port of female personal name Charlotte, and will not directly associate it with protected names "porto" or "port" or wine from Porto. The trade will, therefore, understand controversial term as it transfers the message that disputable trademark is referred to place on the river bank or along the river. Analyzed verdicts shows that terms "direct" and "indirect" use is still unclear, which makes Art. 103, paragraph 2 of Regulation 1308/2013 difficult to apply. As regards the term comparable products, Art 102, paragraph. 1 of Regulation 1308/2013 (products included in one of the categories mentioned in Annex VII, part II) is used analogously. Indications of geographical origin in the sense of Regulation $1308 / 2013$ is referred only to wines.

Regulation 1308/2013 protects reputation of indications of geographical origin even when disputable mark is used for different sort of product. This form of protection is comparable to protection which enjoys famous trademarks according to Art. 7, paragraph 5 of Regulation 2015/2424 (Engelhardt, 2011). Number of litigation in which courts had opportunity to interpret this condition of protection isn't big. The Court of Justice of the European Union in its verdict BNIC COGNAC only briefly pointed out that exploiting of the reputation must be done in disloyal way. In the case PORT CHARLOTTE the Court of Justice of the European Union didn't saw in the disputable trademark, either direct or indirect, use of protected indication of geographical origin. Because of that, there wasn't need to examine reputation of the protected indication. Nevertheless, in the latest verdict "Champagner Sorbet" (Case C-393/16) the Court has opportunity to interpret Art. 103, paragraph 2 (a) of Regulation 1308/2013 (Omsels, 2017). The dispute arisen because German supermarket chain sold frozen product which contained champagne and distributed it under the name "Champagner Sorbet". The Federal Court of Justice of Germany had dilemma is this kind of acting legal or manufacturer and distributor actually exploiting the reputation of the French sparkling wine which has protected indication of geographical origin. In its verdict, the Court proceeded from the fact that use of the name "Champagner Sorbet" to label frozen product which contains champagne can transfer reputation of protected indication "Champagne" to that product, and by this that protected indication arouses the image of quality and prestige, thereby taking advantage of its reputation. At the end, the Court interpreted Art. 103, paragraph 2 (a) of Regulation 1308/2013 in the way that use of protected indication of geographical origin as part of the name under which food is sold and which doesn't comply to specification of that indication, but contains ingredient which complies to mentioned specification, in the meaning of this regulations, if the key characteristic of that food isn't the taste caused in the first place by presence of that ingredient in its composition. 


\section{Protection against any misuse, imitation and alluding}

On this condition of protection the Court of Justice of the European Union had opportunity to make a statement in the "Gorgonzola/Cambozola" verdict (Case C-87/97). The Court, in the trademark "Cambozola" recognized misuse of the "Gorgonzola" protected indication of geographical origin, having in mind that number of the syllables and the end syllables identical. The opinion of the Court was that the misuse is intensified by the fact that trademark Cambozola is also used for blue, that is, mouldy cheese. The Court had once again the chance to interpret this condition in the verdict "Verlados/ Calvados" (Case C-75/15). Calvados is French indication of geographical origin for apple brandy. Verlados is indication for brandy made from apple which is made and sold in Finland. The European Commission had seen the use of the Verlados trademark as misuse of the French indication of geographical origin Calvados. Finnish authorities, on the other hand, accentuated that beverage under the name "Verlados" is local product and that its name directly indicates to the place of production, the village "Verla" and the household "Verla". After the Social and Health Sector Licensing and Supervisory Authority made a decision on ban product placement of the beverage under the name "Verlados", the manufacturer submitted lawsuit to the Market Court. This Court stayed the proceedings and referred a few questions to the Court for a preliminary ruling.

In accordance with its previous practice, the Court noted that "the concept of 'evocation' covers a situation in which the term used to designate a product incorporates part of a protected designation, so that when the consumer is confronted with the name of the product the image triggered in his mind is that of the product whose designation is protected". The Court noted that between the names "Verlados" and "Calvados" there is phonetic and visual relationship. The referring court must take into account the fact that they both contain eight letters, the last four of which are identical, and the same number of syllables, and that they share the suffix 'dos', which confers on them a certain visual and phonetic similarity. For the purposes of assessing the existence of an 'evocation' are important possible informations capable of indicating that the visual and phonetic relationship between the two names is not fortuitous. Namely, the product "Verlados" was originally named "Verla", the suffix 'dos' being added only later, following a significant growth in exports of 'Calvados' to Finland between 1990 and 2001. The syllable 'dos' has not particular meaning in the Finnish language. Those facts are capable of constituting evidence from which it may be concluded that the phonetic and visual relationship between the names "Verlados" and "Calvados" is not fortuitous. The misuse, imitation or evocation may be even if the true origin of the product is indicated.

\section{Protection against all false or misleading indications as to the provenance, origin, nature or essential qualities of the product, on the inner or outer packaging}

European institutions didn't have a chance to declare about this condition of protection. In theory there is opinion that subject of prohibition isn't application of registered indication as such, but application of indirect indication, the one which points out to 
registered indication. These include indications, based on its type, packaging or similar, participants in the trade makes wrong conclusions about products origin. The scope of the prohibition, thereby, aren't just fraud data about geographical origin, but also fraud data about commercial origin, nature or significant characteristics of the good (Tillman, 1992, Mikorey, 2001). Anyway, condition for protection is that specific data is suitable for making wrong impression about product origin. In other words, it's not the actual fraud that's been searched for, but suitability for fraud. Existence of fraud considered is valuated, still, from the view of average informed, careful and reasonable consumer. On this condition of protection the Higher Administrative Court Rhineland-Palatinate had opportunity to declare. The owner of a winery administration used the label "Superior" on the label of one of his wines. In January 2014, the State Investigation Office RhinelandPalatinate informed him that this term was protected for certain wines from Portugal and Spain and therefore should not be used in Germany. Against this the person concerned went to court - with success. The Higher Administrative Court Rhineland-Palatinate in Koblenz ruled that the owner may also use the term "Superior" for wines from Germany, since it does not violate European law on the protection of traditional concepts in wine law. The traditional term is then only protected in Portuguese and Spanish for wine. Here, the plaintiff uses the word "superior", even if it corresponds in spelling to the term protected in Portuguese and Spanish, but to a German wine in German. Because the label is labelled in German language. The controversial statement is also not wrong or misleading. In particular, it was not to be expected that the term 'superior' would mislead an average consumer and that the wine fulfils the conditions of use for the Spanish or Portuguese 'superior' wines. An identical decision was made by the OVG on the use of the term "ANGEL'S RESERVE" on a fully English-language label. Again, this is not the use of the traditional term "reserve", which is protected in Austria.

\section{Protection against any other practice liable to mislead the consumer as to the true origin of the product}

This condition of protection includes all those cases that are not covered by the previous conditions. Considering that previous conditions are widely formulated, practical meaning of this condition is little. Regulation 2015/2424 at Art 8, paragraph. 4(a) prescribed conditions under which indication of geographical origin constitute grounds for objection against Union trademark. This possibility was predicted in Art. 8, paragraph 4 of the earlier Regulation 207/2009. Innovation and advantage of the current regulation is that complainant doesn't have to prove use of indication in trade. Within the complaint procedure, only the assumptions from the Art 103, paragraph 2 of Regulation 1308/2013 are examined. This comes from Art. 8, paragraph 4(a (ii)) of Regulation 2015/2424, which prescribes conditions under which ban of the newer indication can be done. 


\section{Materials and methods}

This work is based at normative and comparative legal method. Large number of judgments made by the Court of Justice and the Court of First Instance has been analyzed, as well as relevant European regulations. The primary hypothesis on which this work is based relates to impediments for protection of geographical indication as trademark in the meaning of the Regulation 1308/2013. Namely, geographical indication because of its descriptive character can not be registered as trademark. Nevertheless, collision between trademarks and geographical indications arises for different reasons. A problem most often occurs when geographical indication is also registered as trademark, with or without additions suitable for distinct them from original mark. A conflict arise also in the case of registration of trademark which is identical or similar to geographical indication from other state, and which is not known as such in the country of registration. In other words, customers from a country of protection experiencing such mark as fantastic designation. Practical problems arises when the circle of authorized persons to older and newer sign does not coincide. The controversial issue that arises in this case is in fact a question of the scope of the rights that both parties can point out in their relations. Even though the topic of this work is actual also for agricultural and food products, as well as alcohol beverages, the work is limited only to the issue of relation between trademarks and indications of geographical origin for wines.

\section{Results}

The theme of this work has great practical significance and it is related to the work of the Intellectual Property Office, the Ministry of Agriculture and courts. Considering importance and actuality of the topic in the world, in this work special attention is dedicated to analysis of the connection between trademarks and geographical indications in the meaning of Regulation 1308/2013. After analyzing a large number of foreign judgments and relevant European regulations, these the following results:

- Regulation 1308/2013 contains the definition of geographical indications.

- Direct or indirect application within the meaning of Art. 103, paragraph 2 (i) of Regulation $1308 / 2013$ exists when the trademark contains indication of geographical origin as a whole.

- Comparable products within the meaning of the same regulation are only those that can be introduced under wine products.

- The reputation of a geographical indication can be used by other products. This examination is not carried out ex officio in the registration procedure.

- It is unclear whether the presumptions of a violation in the sense of Art. 103, par. 2 of the Regulation 1308/2013 is limited to wine trademarks.

- International agreements, in particular bilateral trade agreements between EU countries and third countries, are a convenient instrument for resolving cases of collision between trademarks and indications of geographical origin. 


\section{Discussions}

Analyzed cases show that the European Union can protect certain name as the name of the origin and to ensure that member states respects decisions of the European Commission and the Court of Justice of EU. However, states which aren't members can proceed with use of names protected in Union as the name of origin, with explanation that they considering them as generic, i.e. indications of entire product type. Namely, non-European countries started later production of those products whose names are protected in Europe as the names of origin. Even though production of such products started later than in Europe, this states become world leaders in production. However, the new manufacturers does not respects names of the origin protected in European countries. For example, the Supreme Court of the Brazil in 1974 ruled that name champagne is to be considered generic. Fourteen years later, the law was adopted in Brazil by which names champagne and cognac, as well as their equivalents at the Portuguese language, are marked as generic. France reacted and submitted appeal by Cognac manufacturers Office. In the meantime, Brazil amended controversial law the in 1996, and in that way provided protection to the Cognac name, but translation of this name "conhaque" stayed in free use. States of South America often justifies this kind of act with linguistic and historical reasons. In fact, the Spanish and the Portuguese languages are originated from Latin, as well as languages of the European Union in which names of origin are protected (France, Italy, Spain, Portugal). Production, and specially cultivation of wine, started with colonization of those countries, and colonizers were the Europeans. Colonizers brought with them also the names of those products. According to this theory, there isn't any unconscientiousness on the part of the manufacturers of South America, because in their's countries disputable names always had generic character. The USA has also refers to historical reasons, so they can explain why names that are protected in Europe as names of origin in their country considered generic or semi-generic. Namely, terms such as chianti, burgundy or champagne were at first used by French or Italian immigrants in memory of their country of origin. This practice wasn't disputed by European partners and led to creation of generic terms which have only "spiritual" connection to the original site. Protection from this kind of actions the European Union tried to secure by concluding bilateral agreements with countries of the New World. Good example is agreement on wine trade concluded in 1994 within the EU and Australia. Until this agreement wasn't concluded, Australia has used names of origin protected in Europe as generic names for sorts of vine grape, without linking theirs meaning for specific geographical, climate or technical conditions. Thus, for example, Australian manufacturers produced wine under the name "beaujolais nouveau", which, due to differences in seasons between Australia and Europe, was ready for sale three months earlier than French wine, causing great damage to the French owners of that name of origin. Concluding an agreement with the EU, Australia made a commitment that names protected as names of origin in the EU won't be considered as generic, and in return the Union will provide help in further development of Australian wine growing and acknowledge their names of origin (such 
as South Eastern Australia). Following the example of an agreement with Australia, the European Union in 2002 concluded agreement with the Republic of South Africa. Negotiation between the EU and the USA considering mutual protection of the names of origin, have not given significant results so far, and at bilateral level France succeeded to protect the terms cognac, Armagnac and calvados by agreement with the USA, while in return provided protection to American indications of geographical origin bourbon and bourbon whiskey.

\section{Conclusions}

Protection of indications of geographical origin is complex legal issue with undoubted economic, as well as political consequences (Büscher, 2008, Knaak, 2006). Indications of geographical origin have great commercial importance. Among other things, it brings up at consumers certain ideas about quality of the good (for example). Because of that the question arose in early stage, question about right of use geographical indication for marking good and services. That is, by its nature geographical indication is collective mark which belongs to all persons from geographical area that it refers to. From this reason it is not suitable for use as individual mark. It is suitable for distinguishing the goods of persons operating in the area concerned from the goods of persons operating in another area. Nevertheless, in efforts to find as suitable forms as possible for labelling theirs products, manufacturers use the geographical indications as well. Considering the previously exposed problems related to the protection of geographical indications, their economic importance, as well as different legal nature of trademarks and geographical indications, in this work we analyzed question of collision between trademarks and indications of geographical origin for wines in the light of the current EU regulations and the practice of the Court of Justice of the European Union.

\section{Conflict of interests}

The authors declare no conflict of interest.

\section{References}

1. Büscher, W. (2008): Geographical indications of origin as an object of commercial property or as a controlling instrument of business and politics, Intellectual Property and Copyright, International Part,12, 977-982. [In German: Geographische Herkunftsangaben als Gegenstand des gewerblichen Eigentums oder als Steuerungsinstrument von Wirtschaft und Politik, Gewerblicher Rechtsschutz und Urheberrecht, Internationaler Teil].

2. CaseC-87/97,http://eur-lex.europa.eu/legal-content/EN/TXT/?uri=ecli: ECLI:EU:C:1999:115(December 05, 2017).

3. Case $\mathrm{C}-4 / 10$, http://curia.europa.eu/juris/liste.jsf?language $=$ en\&num $=\mathrm{C}-4 / 10$, (December, 08). 
4. Case C-75/15, http://curia.europa.eu/juris/liste.jsf?\&num=C-75/15 (December, 13).

5. Case C-393/16, http://curia.europa.eu/juris/liste.jsf?num=C-393/16 (January 12, 2018).

6. Case T-237/08, http://curia.europa.eu/juris/liste.jsf?language=en\&num=T-237/08 (January 18, 2018).

7. Case T-55/14, https://dejure.org/dienste/vernetzung/rechtsprechung?Text=T-55/14 (January 22, 2018).

8. CaseT-659/14,http://curia.europa.eu/juris/liste.jsf?language=en\&num=T-659/14 (January 28, 2018).

9. E-Bacchus, http://ec.europa.eu/agriculture/markets/wine/e-bacchus/index.cfm? language $=\mathrm{EN}($ December 10, 2017).

10. Engelhardt, T. (2011): Infringement of EU-protected geographic names. [In German: Die Verletzung EU rechtlich geschützter geografischer Namen], Carl Heymanns Verlag, Köln.

11. Jojić-Novaković, Đ., Cvijanović, D. (2017): Standardisation of wineries as one of preconditions for the growth of wine tourism, $2^{\text {nd }}$ International Scientific Conference - Thematic Proceedings I, Faculty of Hotel Management and Tourism, Vrnjačka Banja, 77-94, http://www.hitvb.kg.ac.rs/conference/images/ thematic proceedings/2017 I.pdf.

12. Jovićević-Simin, M., Jovićević, P., Novaković, S. (2016): Appelations of geographical origin as a generator of national competitiveness, Economics of Agriculture, 63(2), 567-583.

13. Klein, P.J. (2016): The protection of registered designations of origin and geographical indications for Wine-growing products against EU trademarks, Trademark Law, Magazine for German, European and international Trademark Law)5, 235-246. [In German: Der Schutz eingetragener Ursprungsbezeichnungen und geografischer Angaben für Weinbauerzeugnisse gegenüber Unionsmarken, Markenrecht (Zeitschrift für deutsches, europäisches und internationals Kennzeichenrecht].

14. Knaak, R. (2006):The EC Regulation No 510/2006 on the protection of geographical indications and designations of origin, Intellectual Property and Copyright, International Part, 11, 893-901. [In German: Die EGVerordnung Nr. 510/2006 zum Schutz von geographischen Angaben und Ursprungsbezeeichnungen, Gewerblicher Rechtsschutz und Urheberrecht, Internationaler Teil].

15. Loschelder, M. (2015): The legal protection of geographical indications, Trademark Law, Magazine for German, European and international Trademark Law,5, 225-235. [In German: Zum Rechtsschutz der geografischen Herkunftsangaben, Markenrecht, Zeitschrift für deutsches, europäisches und internationals Kennzeichenrecht]. 
16. Mikorey, C. (2001): The protection of geographical indications and designations of origin for agricultural products and foodstuffs under Regulation (EC) No 2081/92, [In German: Der Schutz von geografischen Angaben und Ursprungsbezeichnungen für Agrarerzeugnisse und Lebensmittel in der Europäischen Gemeinschaft nach der VO 2081/92], Peter Lang GmbH, Frankfurt am Main.

17. Omsels, H.J. (2017):The dispute over the champagne sorbet, Trademark Law, Magazine for German, European and international Trademark Law, 1, 19-25. [In German: Der Streit um das Champagner Sorbet, Markenrecht, Zeitschrift für deutsches, europäisches und internationals Kennzeichenrecht].

18. 18.Regulation EU 40/94, http://www.wipo.int/wipolex/en/details.jsp?id=1421 (December 02, 2017).

19. Regulation EU 207/2009, http://eur-lex.europa.eu/legal-content/EN/TXT/ ?uri=CELEX:02009R0207-20160323 (December 02, 2017).

20. Regulation EU 1308/2013, http://eur-lex.europa.eu/legal-content/en/TXT/ ?uri=CELEX:32013R1308 (December 05, 2017).

21. Regulation EU 2015/2424,http://eur-lex.europa.eu/legal-content/EN/TXT/ ?uri=CELEX:32015R2424 (December 05, 2017).

22. Sekulić, D, Mandarić, M, Milovanović, V. (2016): Motivation of travelers for participation in wine tourism in Serbia, Economics of Agriculture, 63(4), 1237-1252.

23. Ströbele, P., Hacker, F. (2015): Trademark Act-Comment, [In German: Markengesetz-Kommentar], Carl Heymanns Verlag, Köln.

24. Tilmann, W. (1992):EU protection for geographical indications, Intellectual Property and Copyright, 12, 829-835. [In German: EG Schutz für geographische Herkunftsangaben, Gewerblicher Rechtsschutzund Urheberrech].

25. TRIPS Agreement, https://www.wto.org/english/docs_e/legal_e/27-trips01e. htm, December 15, 2017).

26. Vujko, A., Gajić, T., Gudurić, I. (2017): Wine trails of Irig municipality, Hotel and tourism management, 5(2), 7-15. [In Serbian: Вујко, А, Гајић, Т., Гудурић, И., (2017), Perpektive razvoja vinskog turizma opštine Irig].

27. Vuković, P., Cecić, N., Cvijanović, D. (2007): Sustainable tourist development of rural areas in Serbia, Economics of Agriculture, 54(3), 369-379. 